\title{
MENGUAK PSIKOLOGI ISLAM MELALUI PENDEKATAN SEJARAH
}

\author{
Sudirman \\ IAI Al Khoziny Buduran Sidoarjo \\ sudirman@gmail.com
}

\begin{abstract}
The psychological approach in Islamic studies has a significant role in explaining the external symptoms of religious people. Armed with psychological theories, it will be easy to know the level of religion a person understands, lives and practices. This paper aims to explain and analyze Islamic psychology based on a historical approach and analyze western psychology schools using an Islamic psychological approach. This study refers to the history of Islamic psychology from the 19th century to the modern era at this time, and also how the development of religious psychology. The results in this article are that humans have the potential to do good from the aspects of will, freedom, feelings, and thoughts to reveal the meaning of life based on monotheistic values so that humans are able to develop the potential and quality of Islamic life, namely by integrating the pyramid relationship between lust, intellect, and heart into the human psychological context based on the teachings of revelation that will give birth to a creative life as ordered by God in the Koran.
\end{abstract}

Keywords: Psychology, Religion, Islamic Principles, Psychology of Religion 


\section{PENDAHULUAN}

Dalam realitas kehidupan di dunia ini ada Sang Khalik (pencita) yakni Allah Swt dan Makhluk (yang diciptakan) meliputi malaikat, jin, hewan, tumbuhan dan alam semesta. Salah satu ciptaan Allah adalah manusia, yang diberi keistimewaan berupa kemampuan berpikir yang melebihi jenis makhluk lain yang sama-sama menjadi penghuni bumi. Kemampuan berpikir itulah yang diperintahkan Allah agar dipergunakan untuk mendalami wujud atau hakikat dirinya dan tidak semata-mata dipergunakan untuk memikirkan segala sesuatu di luar dirinya.Demikianlah kenyataannya bahwa manusia tidak pernah berhenti berpikir, kecuali dalam keadaan tidur atau sedang berada dalam situasi diluar kesadaran. Manusia berpikir tentang segala sesuatu yang tampak atau dapat ditangkap oleh pancaindera bahkan yang abstrak sekalipun. Psikologi merupakan suatu cabang ilmu pengetahuan yang terbilang masih baru dan diakui pada akhir abad ke-18 M. Hal ini berawal ketika Wilhelm Wundt (1832-1920). memiliki ketertarikan pada bidang fisiologi. Wundt kemudian melakukan pendekatan eksprimental dalam pendekatan studi psikologi. Menurut Djamaludin Ancok,1 usaha yang dapat digunakan untuk mengintegrasikan psikologi dan Islam adalah membentuk konsep psikologi baru yang didasarkan pada Islam. Cara tersebut sangatlah bisa ditempuh mengingat kandungan al-Qur'an yang berpeluang membentuk suatu konsep psikologi yang berwawasan Islam. ${ }^{1}$ Psikologi ini terus mengalami perkembangan. Keadaan inilah yang kemudian mengantarkan lahirnya psikologi Islam.

Pengkajian psikologi agama di dunia Timur (Islam) telah dikenal sebelum dunia barat mengkajinya. Hal ini dapat dibuktikan melalui beberapa karya fenomenal ilmuwan muslim yang mengkaji terkait dinamika keagamaan dan psikologi seseorang, di antaranya adalah karya Ibnu Thufail (1110-1185) dan al-Ghazali (1059-1111). Karya yang berjudul Hayn Ibn Yazan yang ditulis oleh Ibnu Tufail membahas masalah proses pertumbuhan dan perasaan agama dari seorang anak yang dilahirkan di pulau terpencil. Adapun karya Al-Ghazali yang berjudul alMunqiz Mina al-Dholal (penyelamat dari kesesatan) banyak membahas tentang dimensi psikologi dan keagamaan seseorang.

Dalam Psikologi Islam terdapat beberapa hal yang dianggap penting, pertama bahwa psikologi Islam menitik beratkan pada aspek pengaruh. Dengan demikan, ada yang menyebut bahwa psikologi Islam

\footnotetext{
${ }^{1}$ Djamaludin Ancok \& Fuat Nashori Suroso, Psikologi Islam, Solusi Islam atas Problemproblem Psikologi, (Jakarta: Pustaka Pelajar, 2004), hal. 3.
} 
sebagai ilmu pengaruh, yaitu ilmu yang mempelajari sikap dan perilaku seseorang sebagai hasil pengaruh dari keyakinan atau kepercayaan agama yang dianutnya. Kedua bahwa psikologi Islam mengkaji proses terjadinya pengaruh suatu kepercayaan atau keyakinan dalam menumbuhkembangkan jiwa keagamaan seseorang. Ketiga bahwa psikologi Islam mengkaji "kondisi" keagamaan seseorang. Apabila terjadi kemantapan ataupun kegoncangan jiwa dalam keberagamaannya juga menjadi objek kajian penting dalam psikologi Islam.

Psikologi Islam sebenarnya telah muncul sejak masa Islam awal yang disebut dengan periode Klasik. Periode ini dimulai pada masa Nabi Muhammad saw. Namun pada saat itu pembahasan psikologi Islam hanya berkisar kepada pembahasan tentang nafs atau jiwa, yang menghasilkan dua kelompok. ${ }^{2}$ Periode berikutnya yaitu periode modern dimulai pada tahun 1950-an di Amerika yang ditandai dengan munculnya gerakan psikologi Islam yang muncul karena adanya dorongan tuntutan nyata untuk menghadapi krisis yang dihadapi umat manusia. Pada tahun 1978, diadakan Symposium on Psychology and Islam di Riyadh. Hal ini menandakan adanya perkembangan dari psikologi Islam itu sendiri. Di Indonesia, psikologi Islam juga mengalami perkembangan. ${ }^{3}$ Dengan demikian, dalam artikel ini Penulis akan menjelaskan ilmu jiwa/ psikologi agama dalam pandangan Islam.

\section{METODE}

Penelitian ini menggunakan pendekatan penelitian kualitatif dengan jenis penelitian deskriptif analitik. Adapun Teknik pengumpulan data yaitu studi literature. Penelitian kualitatif merupakan jenis penelitian yang mengumpulkan data berupa kata-kata yang digunakan sebagai

\footnotetext{
${ }^{2}$ Kelompok pertama merupakan generasi ulama awal yang membahas tentang nafs atau jiwa semata-mata hanya bersumber dari al-Quran dan Hadits dan berlangsung sejak zaman Nabi Muhammad saw hingga masa Daulah Bani Umayyah. Kelompok ini nantinya akan berkembang menjadi ilmu kalam dan tasawuf. Adapun salah satu tokoh yang berasal dari kelompok ini adalah Imam Ghazali. Kelompok kedua muncul pada masa pemerintahan Abbasiyah. Kelompok ini tidak hanya menjadikan al-Quran dan Hadits sebagai landasan dari jiwa, melainkan juga menggunakan filsafat Yunani sebagai landasan dari pembahasan terkait jiwa. Hal ini merupakan dampak dari maraknya gerakan penerjemahan yang dilakukan pada masa itu. Lihat Erma Yudiani, "Pengantar Psikologi Islam”, dalam, JIA, Nomor 2/Th. XIV, Desember 2013, hlm. 176-177.

3 Perkembangan psikologi Islam di Indonesia ditandai dengan bermunculannya jurnaljurnal psikologi Islam, seperti Jurnal Pemikiran Psikologi Islam KALAM di Universitas Gadjah Mada dan Simposium Nasional Psikologi Islami di Universitas Muhammadiyah Surakarta pada tahun 1996. Selain jurnal, buku-buku yang berkaitan dengan pemikiran psikologi Islam juga gencar diterbitkan. Lihat Ibid.
} 
sumber data dan bukan menggunakan angka sebagai objek penelitiannya. Penelitian kualitatif memiliki tujuan untuk memahami fenomena yang terjadi didalam kehidupan oleh subjek penelitian di lapangan. Adapun jenis penelitian ini menggunakan deskriptif analitik dimana peneliti tidak hanya menjelaskan fenomena tertentu, tetapi peneliti turut serta melakukan analisis terhadap fenomena yang terjadi sesuai dengan yang terjadi di lapangan.

Seperti yang telah dijelaskan diatas, penelitian ini menggunakan Teknik pengumpulan data berupa studi literature untuk mengumpulkan data-data sebagi sumber utama penelitian ini sehingga penelitian ini validasi yang tinggi sesuai yang terjadi di lapangan. Kemudian, setelah peneliti mendapatkan literature yang sesuai dengan penelitian ini. Kajian pengembangan karakter kepribadian anak usia dasar akan dilakukan dengan melakukan analisis data sesuai dengan literature yang ada dalam penelitian ini.

\section{HASIL DAN PEMBAHASAN}

Agama sebagai bentuk keyakinan, memang sulit diukur secara tepat dan rinci. Hal ini pula barangkali yang menyulitkan para ahli untuk memberikan definisi yang tepat tentang agama. Dan walaupun J.H. Leuba dalam bukunya Al-Qur'an Psyshological Study of Religion telah memasukkan lampiran yang berisi 48 definisi tentang agama tak ada gunanya, karena hanya merupakan kepandaian mencari kata-kata yang dapat digunakan untuk membuat definisi agama.

Robert H. Thouless (1992: 25), dengan definisi itu ingin membedakan sikap-sikap yang bersumber dari suatu kepercayaan agama terhadap yang bersumber bukan dari agama, walaupun dalam realitasnya terdapat sikap yang sama. Sehubungan dengan hal itu, Thouless berpendapat, bahwa psikologi agama adalah cabang dari psikologi, yang bertujuan mengembangkan pemahaman terhadap perilaku keagamaan dengan mengaplikasikan prinsip-prinsip psikologi yang dipungut dari kajian terhadap perilaku bukan keagamaan.

Menurut Zakiah Daradjat (1970: 11), psikologi agama meneliti dan menelaah kehidupan seseorang dan mempelajari beberapa besar pengaruh keyakinan agama itu dalam sikap dan tingkah laku, serta keadaan hidup pada umumnya. Di samping itu, psikologi agama juga mempelajari pertumbuhan dan perkembangan jiwa agama pada seseorang, serta faktor-faktor yang memengaruhi keyakinan tersebut. Psikologi agama, dengan demikian merupakan cabang psikologi yang meneliti dan mempelajari tingkah laku manusia dalam hubungan dengan 
pengaruh keyakinan agama yang dianutnya serta dalam kaitannya dengan perkembangan usia masing-masing. Upaya untuk mempelajari tingkah laku keagamaan tersebut dilakukan melalui pendekatan psikologi. Jadi, penelaahan tersebut merupakan kajian empiris.

\section{Kajian Ilmu Jiwa/ Psikologi Agama}

Sebagai disiplin ilmu yang otonom, psikologi agama memiliki ruang lingkup pembahasannya tersendiri yang dibedakan dari disiplin ilmu yang mempelajari masalah agama dan ilmu perbandingan agama di mana keduanya memiliki tujuan yang tak jauh berbeda, yang mengembangkan pemahaman terhadap agama dengan mengaplikasikan metode-metode penelitian yang bertipe bukan agama bukan teologis. Bedanya adalah, bila ilmu perbandingan agama cenderung memusatkan perhatiannya pada agama-agama primitif dan eksotis yang bertujuan untuk mengembangkan pemahaman dengan membandingkan suatu agama dengan agama lainnya. Sebaliknya, psikologi agama, seperti pertanyaan Robert $H$. Thouless (1992: 25), memusatkan kajiannya pada agama yang hidup dalam budaya suatu kelompok atau masyarakat itu sendiri. Kajiannya terpusat pada pemahaman terhadap perilaku keagamaan tersebut dengan menggunakan pendekatan psikologi.

Psikologi agama menurut Prof. Dr. Zakiah Daradjat, adalah mempelajari kesadaran agama pada seseorang yang pengaruhnya terlihat dalam kelakuan dan tindak tanduk agama orang itu dalam hidupnya. Persoalan pokok dalam psikologi agama adalah kajian terhadap kesadaran agama dan tingkah laku agama, Robert H. Thouless (1992: 11), atau kajian terhadap tingkah laku agama dan kesadaran agama. Seperti diketahui, bahwa psikologi agama sebagai salah satu cabang dan psikologi juga merupakan terapan. Psikologi agama sejalan dengan ruang lingkup kajiannya telah banyak memberikan sumbangan dalam memecahkan persoalan kehidupan manusia dalam kaitannya dengan agama yang dianutnya. Kemudian, bagaimana rasa keagamaan itu tumbuh dan berkembang pada diri seseorang dalam tingkat usia tertentu; bagaimana perasaan keagamaan itu dapat memengaruhi ketentraman batinnya, dan berbagai konflik yang terjadi dalam diri seseorang hingga ia menjadi lebih taat menjalankan ajaran agamanya atau meninggalkan ajaran itu sama sekali $^{4}$

\footnotetext{
${ }^{4}$ Jalaluddin Rahmad, Psikologi Agama (sebuah pengantar), Jakarta: Mizan Media Buku Utama, 2003, h.17
} 
Lebih lanjut, Zakiah Daradjat menyatakan, bahwa lapangan penelitian psikologi agama mencakup proses beragama, perasaan, dan kesadaran beragama dengan pengaruh dan akibat-akibat yang dirasakan sebagai hasil dari keyakinan. Oleh karena itu, menurut Zakiah Daradjat, ruang lingkup yang menjadi lapangan kajian psikologi agama meliputi kajian mengenai:

1. Bermacam-macam emosi yang menjalar di luar kesadaran yang ikut menyertai kehidupan beragama orang biasa, seperti rasa lega dan tentram sehabis sembahyang; rasa lepas dari ketegangan batin sesudah berdoa atau membaca ayatayat suci; perasaan tenang pasrah, dan menyerah setelah berzikir; dan ingat kepada Allah ketika mengalami kesedihan dan kekecewaan yang bersangkutan.

2. Bagaimana perasaan dan pengalaman seseorang secara individual terhadap Tuhannya, misalnya rasa tentram dan kelegaan batin.

3. Mempelajari, meneliti, dan menganalisis pengaruh kepercayaan akan adanya hidup sesudah mati pada tiap-tiap orang.

4. Meneliti dan mempelajari kesadaran dan perasaan orang terhadap kepercayaan yang berhubungan dengan surga dan neraka, serta dosa dan pahala yang turut memberi pengaruh pengaruh terhadap sikap dan tingkah lakunya dalam kehidupan.

5. Meneliti dan mempelajari bagaimana pengaruh penghayatan seseorang terhadap ayat-ayat suci untuk kelegaan batinnya.

\section{Pentingnya Ilmu Jiwa/ Psikologi Agama dalam Pendidikan Islam}

Pendidikan Islam di sini diartikan sebagai upaya sadar yang dilakukan oleh mereka yang memiliki tanggung jawab terhadap pembinaan, bimbingan, pengembangan serta pengarahan potensi yang dimiliki anak agar mereka dapat berfungsi dan berperan sebagaimana hakikat kejadiannya. Jadi, dalam pengertian ini, pendidikan Islam tidak dibatasi oleh institusi ataupun pada lapangan pendidikan tertentu. Pendidikan Islam diartikan dalam ruang lingkup yang luas. Adapun yang dimaksud dengan bertanggung jawab dalam pengertian ini adalah orang tua. Sedangkan, para guru atau pendidik lainnya adalah perpanjangan tangan orang tua..$^{5}$ Maksudnya, tepat tindakan para guru atau pendidik yang dipilih oleh orang tua untuk mendidik anak mereka sepenuhnya menjadi tanggung jawab orang tua. Maka, pendidikan Islam meletakkan dasarnya pada rumah tangga. Seiring dengan tanggung jawab itu, maka orang tua dan para guru dalam pendidikan Islam berfungsi dan berperan sebagai pembina, pembimbing, pengembang serta pengarah potensi yang

${ }^{5}$ Jalaludin, Psikologi Agama, Jakarta: Grafindo Persada. 2001, h. 11 
dimiliki anak agar mereka menjadi pengabdi Allah yang taat dan setia, sesuai dengan hakikat penciptaan manusia dan juga dapat berperan sebagai khalifah Allah dalam kehidupan di dunia. Selain itu, dalam pelaksanaannya, aktivitas pendidikan seperti itu diterapkan sejak usia bayi dalam buaian hingga ke akhir hayat, seperti tuntutan Rasulullah Saw.

Pendekatan psikologi agama dalam pendidikan Islam itu ternyata telah dilakukan di periode awal perkembangan Islam itu sendiri. Fungsi dan peran kedua orang tua sebagai teladan yang terdekat kepada anak yang telah diakui dalam pendidikan Islam. Bahkan, agama dan keyakinan seorang anak dinilai sangat tergantung dari keteladanan para orang tua mereka. ${ }^{6}$ Tak heran jika Sigmund Freud (1856-1939) menyatakan bahwa keberagaman anak terpola dari tingkah laku bapaknya. Jika kesadaran pengarah bapak terhadap keberagamaan anak baru diungkapkan oleh ahli psikologi agama (Barat) sekitar awal abad ke-20, maka jauh sebelum itu Islam telah menerapkan dalam kehidupan rumah tangga. Bahkan, menurut pendidikan Islam, bukan hanya bapak, melainkan juga ibu ikut memberi citra pada keberagamaan anak-anak mereka.

Dalam informasi Al-Qur'an ini mengungkapkan bagaimana seharusnya bapak menuntun dan membimbing anak-anak mereka mengenal Tuhannya. Anak mengenal Tuhan melalui bimbingan orang tua mereka. Kemudian, upaya membimbing pengenalan terhadap Tuhan dan agama hendaknya dilakukan dengan penuh kasih sayang. Tidak dengan perintah, melainkan melalui keteladanan orang tua. Dalam pandangan Islam sejak manusia dilahirkan, manusia telah dianugerahkan potensi keagamaan. Potensi ini baru dalam bentuk sederhana, yaitu berupa kecenderungan untuk tunduk dan mengabdi kepada sesuatu. Agar kecenderungan tunduk dan mengabdi ini tidak salah, maka perlu adanya bimbingan dari luar. Secara kodrati orang tua merupakan pembimbing pertama yang mula-mula dikenal anak. Oleh karena itu, Rasulullah menekankan bimbingan itu pada tanggung jawab kedua orang tua.

\section{Perkembangan Ilmu Jiwa/ Psikologi Agama}

Sebagai disiplin ilmu boleh dikatakan, psikologi agama dapat dirujuk dari karya tulis Barat, antara lain karya Jonathan Edward, Emile Durkheim, Edward B. Taylor maupun Stanley Hall yang memuat kajian mengenai agama suku-suku primitif dan mengenai konversi agama. Kajian sosiologi dan antropologi budaya ini menampilkan sisi-sisi kehidupan masyarakat suku primitif dan sikap hidup mereka terhadap

\footnotetext{
${ }^{6}$ Ahmad Fauzi, Psikologi Umum, Bandung : Pustaka Setia, 2004, h. 9
} 
sesuatu yang dianggap sebagai adikodrati (supernatural). Selanjutnya, tulisan-tulisan yang memuat pembahasan secara khusus tentang psikologi agama baru terbit.

Berdasarkan sumber Barat, para ahli psikologi agama mulai populer sekitar akhir abad ke-19 sekitar masa itu psikologi yang semakin berkembang digunakan sebagai alat untuk kajian agama. Kajian semacam itu dapat membantu pemahaman terhadap cara bertingkah laku, berpikir, dan mengemukakan perasaan keagamaan (Robert H. Thouless, 1992: 7). Sebaliknya di dunia Timur, khususnya di wilayah-wilayah kekuasaan Islam, tulisan-tulisan yang memuat kajian tentang hal serupa belum sempat dimasukkan. Padahal, tulisan Muhammad Ishaq ibn Yasardi abad ke-7 M, berjudul Al-Siyar wa al-Maghazi memuat beberapa fragmen dari biografi Nabi Muhammad Saw., (Ensiklopedi Islam, 1992: 361), ataupun risalah Hayy ibnu Yaqzan fi asrar al-hikmat al-Masyrigyyat yang ditulis oleh Abu Bakar Muhammad ibn Abd al-Malik ibn Tufail (1106-1188 M). Juga memuat masalah yang erat kaitannya dengan materi psikologi agama. $^{7}$

Menurut Thouless, sejak terbitnya buku The Varietes of Religious Experience tahun 1903, sebagai kumpulan dari materi kuliah William James di empat Universitas di Skotlandia, langkah awal dari kajian psikologi agama mulai diakui para ahli psikologi dan dalam jangka waktu tiga puluh tahun kemudian, banyak buku-buku lain diterbitkan sejalan dengan konsep-konsep yang serupa. Sejak itu, kajian-kajian tentang psikologi tampaknya tidak hanya terbatas pada masalah-masalah yang menyangkut kehidupan keagamaan secara umum, melainkan juga mengenai masalah-masalah khusus. J.B. Pratt misalnya, kajian mengenai kesadaran beragama melalui bukunya Religious Consciousness (1920). Selanjutnya, kajian-kajian psikologi agama juga tidak terbatas pada agama-agama yang di Timur. A.J. Appasamy dan B.H. Streeter menulis tentang masalah yang menyangkut kehidupan penganut agama Hindu dengan bukunya The Sadhu (1921) (Jalaluddin, 2004: 6).

Lebih jauh, Marshall G.S. Hodgson melihat hal itu lebih disebabkan oleh faktor intern umat Islam sendiri. Menurutnya, masyarakat Islam gagal memelopori kemodernan karena tiga hal, yaitu:

1. Konsentrasi yang kelewat besar pada penanaman modal harta dan manusia pada bidang-bidang tertentu, sehingga

\footnotetext{
${ }^{7}$ Jalaluddin Rahmad, Psikologi Agama (sebuah pengantar), Jakarta: Mizan Media Buku Utama, 2003, h.17
} 
pengalihannya kepada bidang lain merupakan kesulitan yang luar biasa.

2. Kerusakan hebat baik material maupun mental psikologis, akibat serbuan biadab bangsa Mongol.

3. Kecemerlangan peradaban Islam sebagai suatu bentuk pemuncakan abad agraria membuat kaum muslimin tidak pernah merasa perlu kepada peningkatan yang lebih tinggi. Ia menyimpulkan bahwa dunia Islam berhenti berkembang karena kejenuhan dan kemantapan pada diri sendiri (Nurcholish Madjid, 1984: 54).

Terlepas darimana alasan dan penyebab yang paling tepat, memang setelah zaman kemunduran umat Islam secara politis, kemajuan dan perkembangan ilmu pengetahuan dan teknologi dipelopori oleh Barat. Dengan demikian, tidak mengherankan jika ilmu-ilmu modern, termasuk psikologi agama tumbuh dan berkembang sebagai sebuah disiplin ilmu yang independen, yang diakui terinformasikan sebagai produk ilmuwan Barat. Dan baru setelah negara-negara Islam bebas dari kungkungan penjajah Barat, secara bertahap muncul karya-karya ilmuwan Muslim.

Perkembangan psikologi agama yang cukup pesat ini antara lain ditandai dengan diterbitkannya berbagai karya tulis, baik berupa buku maupun artikel dan jurnal yang memuat kajian tentang bagaimana peran agama dalam kehidupan manusia. Dengan demikian, psikologi agama kini telah memasuki berbagai bidang kehidupan manusia, sejak dari rumah tangga, sekolah, institusi keagamaan, dan bahkan hingga ke lembaga kemasyarakatan.

\section{Ilmu Jiwa/ Psikologi Agama dalam Islam}

Secara terminologis, memang psikologi agama tidak dijumpai dalam kepustakaan klasik, karena latar belakang perkembangannya bersumber dari literatur Barat. Dan kalangan ilmuwan Barat yang mulamula menggunakan sebutan psikologi agama adalah Edwin Diller Starbuck, melalui karangannya Psychology of Religion yang terbit tahun 1899. Namun, hal ini tidak berarti bahwa di luar itu studi yang berkaitan dengan psikologi agama belum pernah di lakukan oleh para ilmuwan non-Barat. Meskipun dikalangan ilmuwan Muslim, kajian-kajian dalam psikologi agama mulai dilakukan secara khusus sekitar pertengahan abad ke-20, namun permasalahan yang ada sangkutpautnya dengan bidang kajian ini sudah berlangsung sejak awal perkembangan Islam. ${ }^{8}$

${ }^{8}$ H. Ramayulis, Psikologi Agama, Kalam Mulia 2004. Hal 34 
Kenyataan ini dapat dilihat dari berbagai konsep ajaran Islam yang dapat dijadikan acuan dalam studi psikologi agama. Sudah sejak lama AlQur'an menginformasikan bahwa manusia makhluk ciptaan Tuhan memiliki sosok diri yang terbentuk dari unsur fisik dan non-fisik. Secara anatomis, pemahaman terhadap unsur fisik tampaknya jauh berbeda dari konsep manusia menurut pandangan ilmuwan Barat, meskipun dalam pengertian khusus konsep Islam tentang manusia lebih rinci. Manusia menurut terminologi Al-Qur'an dapat dilihat dari berbagai sudut pandang. Manusia disebut al-Hasyar berdasarkan aspek biologisnya. Dan sudut pandang ini manusia dilihat sebagai makhluk biologis yang memiliki dorongan primer (makan, minum, hubungan seksual) dan makhluk generatif (berketurunan). Sedangkan dilihat dari fungsi dan potensi yang dimilikinya manusia disebut al-Insan.

Konsep al-Insan menggambarkan fungsi manusia sebagai penyandang khalifah Tuhan yang dikaitkan dengan proses penciptaan dan pertumbuhan serta perkembangannya (QS Al-Baqarah [2]: 30 dan QS Al-Mu'minuun [23]: 12-14). Selain itu, konsep al-Insan juga menunjukkan potensi yang dimiliki manusia seperti kemampuan untuk mengembangkan ilmu (QS Al-'Alaq [96]: 4-6). Di samping itu, konsep ini juga menggambarkan sejumlah sifat-sifat dan tanggung jawab manusia seperti lupa, khilaf, tergesa-gesa, suka membantah, kikir, tidak bersyukur dan sebagainya. Namun, kepadanya dibebankan amanah dan tanggung jawab untuk bersifat baik (QS Maryam [19]: 8).

\section{KESIMPULAN}

Psikologi Islam adalah ilmu yang meneliti pengaruh agama terhadap sikap dan tingkah laku seseorang atau mekanisme yang bekerja dalam diri seseorang yang menyangkut cara berfikir, bersikap, bereaksi, dan bertingkah laku, yang tidak terpisahkan dari keyakinannya, karena keyakinan itu masih dalam konstruk kepribadian seseorang. Psikologi Islam berkaitan erat dengan pendidikan Islam dan kesehatan mental. Psikologi Islam dijadikan sebagai pendekatan dalam pendidikan Islam untuk menciptakan orang-orang yang memiliki kesehatan mental. Dengan demikian, hal-hal yang tidak seharusnya terjadi di lingkungan pendidikan akan dapat diperbaiki. ${ }^{9}$

Psikologi Islam digunakan sebagai pendekatan dalam pendidikan Islam untuk memperlancar visi dan misi dari penyelenggaraan pendidikan Islam itu sendiri. Psikologi Islam juga digunakan untuk meminimalisir

${ }_{9}^{9}$ WE Maramis, Ilmu Kedoteran Jiwa, Airlangga University Press, 1980. Hal 22-23 
keadaan yang tidak seharusnya terjadi di dunia pendidikan saat ini, seperti sikap membantahnya seorang murid kepada gurunya dan lain-lain. Hal itu digunakan untuk menciptakan manusia dengan tingkat kesehatan mental yang baik, yaitu manusia yang bertindak sesuai dengan ajaran agama yang ia yakini. 


\section{DAFTAR PUSTAKA}

Ancok, Djamaludin \& Fuat Nashori Suroso, Psikologi Islam, Solusi Islam atas Problem-problem Psikologi, Jakarta: Pustaka Pelajar, 2004.

Rahmad, Jalaluddin. Psikologi Agama (sebuah pengantar), Jakarta: Mizan Media Buku Utama, 2003.

Jalaludin, Psikologi Agama, Jakarta: Grafindo Persada. 2001.

Fauzi, Ahmad. Psikologi Umum, Bandung: Pustaka Setia, 2004.

H. Ramayulis, Psikologi Agama, tt: Kalam Mulia, 2004.

Maramis,WE. Ilmu Kedoteran Jiwa, tt: Airlangga University Press, 1980. 